ISSN 1412-2936

EISSN 2549-7308

\title{
MODEL MANAJEMEN PEMASARAN PRODUSEN SANDAL DALAM PENINGKATAN SEKTOR UMKM DI DESA PRAGAAN DAYA KAB. SUMENEP \\ MODEL OF MANAGEMENT MARKETING SANDAL PRODUCER IN THE IMPROVEMENT OF UMKM SECTOR IN PRAGAAN DAYA SUMENEP
}

\author{
LUTFIYANTO \\ lutfiyanto.kece@gmail.com \\ STIE Bakti Bangsa Pamekasan
}

\begin{abstract}
ABSTRAK
UMKM merupakan bagian yang penting untuk dikembangkan oleh pemerintah daerah. Dalam mengembangkan UMKM perlu adanya suatu model kajian yang komprehensif sehingga mudah dalam melakukan perumusan kebijakan, program pengembangan dan kegiatan pengembangan UMKM khususnya Desa Pragaan Daya sesuai dengan visi dan misinya dalam membangun Desa Pragaan Daya yang bermartabat. Berdirinya produsen sandal di desa Pragaan Daya merupakan salah satu upaya peningkatan sektor UMKM di desa tersebut. Kajian ini menggunakan pendekatan konseptual dengan pendekatan manajemen pemasaran dalam membuat model pengembangan UMKM Desa Pragaan Daya. Model kajian ini dapat menghasilkan arahan dan gambaran mengenai perumusan sistem pemasaran dan kegiatan yang dapat mengembangkan UMKM di Desa Pragaan Daya sehingga kesejahteraan masyarakat dapat meningkat.
\end{abstract}

Kata kunci: Manajemen Pemasaran, UMKM.

\begin{abstract}
UMKM is an important thing to be developed by local goverment. in developing UMKM needs a comprehensive model of study to be easier in formulating some policies, development programs and development activities of UMKM, especially in Pragaan Daya village in accordance with its vision and mission in building Pragaan Daya village with dignity. The establishment of $b$ sandal producers in Pragaan Daya village is one of the effort to increase the UMKM sector in that village. This study use a conceptual approach and a marketing management approach in modeling the development of UMKM Pragaan Daya. This study can deliver some an instruction and descriptions about formulation of marketing system and some activities that can develop UMKM in Pragaan Daya village. In conclussion, the result of this study can increase the public welfare
\end{abstract}

Keywords: marketing management, UMKM 


\section{PENDAHULUAN}

Perkembangan dunia usaha dewasa ini ditandai dengan makin tajamnya persaingan. Oleh karena itu, peranan pemasaran semakin penting dan merupakan ujung tombak setiap perusahaan. Keberhasilan usaha suatu perusahaan ditentukan oleh keberhasilan pemasarannya. Pemasaran merupakan kunci keberhasilan usaha perusahaan. Setiap perusahaan menginginkan produk yang dihasilkannya dapat terjual atau dibeli oleh konsumen tingkat akhir dengan tingkat harga yang memberikan keuntungan perusahaan jangka panjang. Melalui produk yang dapat dijual, perusahaan dapat menjamin kehidupannya atau menjaga kestabilan usahanya dan berkembang. Peningkatan produksi tidak akan ada artinya bila tambahan produksi tersebut tidak diserap oleh pasar. Dalam rangka inilah setiap produsen harus bisa dalam memasarkan produk agar produknya laku dan pemasarannya tepat sasaran serta bisa tetap bertahan di tengah-tengah gelombang persaingan untuk memasuki pasar yang kompetitif. Untuk itu perlu adanya manajemen pemasaran yang dilakukan suatu perusahaan dalam memasarkan produknya. Manajemen pemasaran selalu diperlukan karena di dalam pengalaman menunjukkan bahwa keragaman perusahaan adalah berfluktuasi.

Pemasaran merupakan kegiatan manusia yang diarahkan untuk memenuhi dan memuaskan kebutuhan dan keinginan melalui proses pertukaran. Selain itu pemasaran juga dapat diartikan sebagai kegiatan meneliti kebutuhan dan keinginan konsumen (search), menghasilkan barang dan jasa sesuai dengan kebutuhan dan keinginan konsumen (product), menentukan tingkat harga (price), mempromosikannya agar produk dikenal konsumen (promotion), dan mendistribusikan produk ke tempat konsumen (place). Keempat variabel tersebut yang akan menentukan tingkat keberhasilan pemasaran dan semua itu ditujukan untuk memberikan kepuasan pada pangsa pasar atau konsumen yang dipilih.

Berbagai faktor \& kekuatan di luar bagian pemasaran yang mempengaruhi kemampuan manajemen pemasaran untuk mengembangkan dan memelihara hubungan baik dengan pelanggan (lingkungan pemasaran) merukan perioritas dalam kegiatan perikonomian di desa.

Sebagai salah satu industri yang menjadi prioritas pembangunan saat ini, industri sandal telah mengalami perkembangan yang cukup signifikan. Gambaran sektor industri non-migas selama tahun 2000-2004, menunjukkan sektor industri ini mengalami pertumbuhan rata-rata sebesar 6 persen pertahun dan hampir sekitar 60 persen output sektor industri ini didominasi oleh industri padat tenaga kerja yang didalamnya termasuk industri sandal, industri TPT (Tekstil dan Produk Tekstil), dan industri pengolahan logam bukan mesin. Sehingga peran sektor industri terhadap perekonomian nasional telah meningkat yaitu dari 23,8 persen pada

Sejarah berdirinya Home Industry Sandal dusun Blumbang desa Pragaan Daya dimulai pada tahun 2015, yang diprakarsai oleh bapak Haruji, warga dusun Blumbang desa Pragaan Daya Kab. Sumenep Pada waktu itu sandal yang dibuat masih sangat sederhana, dengan cara pengerjaannya yang sangat sederhana pula. Pada awal produksinya, sandal tersebut dibuat dengan motiv tulisan di bagian atas sendal, hal itu senada dengan minat masyarakat saat itu.

Seiring berkembangnya zaman, maka muncul ide baru dari tangan pengrajin sandal untuk membuat beberapa motiv dan model sandal, mulai dari sandal jepit, hight sandal, dan selop. pemilik home industri ini adalah warga dusun Blumbang-Pragaan Daya yang sekarang telah memperkerjakan 25 karyawan. Kualitas produk yang dihasilkan oleh Home Industri tersebut banyak diminati pelanggan, dikarenakan hasil inovasi dan ide pembuatan yang dibuat semakin inovatif dan mengikuti zaman, menawarkan produk untuk semua kalangan dari anak-anak sampai dewasa 
dengan berbagai model dan kualitas produk yang bagus. Bahkan penjualannya tidak hanya dalam daerah, namun sudah tersebar ke daerah-daerah lain. Dengan adanya manajemen pemasaran, diharapkan Home Industry Sandal dusun Blumbang desa Pragaan Daya ini dapat meningkatkan volume penjualannya. Jika perusahaan tersebut mampu menerapkan manajemen pemasaran, maka akan tercapai hasil yang lebih maksimal, yang diharapkan dapat meningkatkan volume penjualan.

Berdasarkan uraian di atas dan rumusan masalah dari penelitian ini maka tujuan yang hendak dicapai adalah mengetahui dan menganalisis model manajemen pemasaran sandal di desa Pragaan Daya.

\section{TINJAUAN TEORITIS}

UMKM adalah unit usaha produktif yang berdiri sendiri, yang dilakukan oleh orang perorangan atau Badan Usaha disemua sektor ekonomi (Tambunan, 2012:2). Pada prinsipnya, pembedaan antara Usaha Mikro (UMi), Usaha Kecil (UK), Usaha Menengah (UM) dan Usaha Besar (UB) umumnya didasarkan pada nilai asset awal (tidak termasuk tanah dan bangunan), omset rata-rata pertahun atau njumlah pekerja tetap. Namun definisi UMKM berdasarkan ketiga alat ukur ini berbeda disetiap Negara.

Karena itu, memang sulit membandingkan pentingnya atau peran UMKM antar Negara. Tidak terdapat kesepakatan umum dalam membedakan sebuah Mikro Ekonomi (MiE) dari sebuah UK atau UK dari sebuah UM, dan yang terakhir dari sebuah UB. Namun demikian, secara umum, sebuah UMi mengerjakan lima atau kurang pekerja tetap, walaupun banyak usaha dari kategori ini tidak mengerjakan Di Indonesia, definisi UMKM diatur berdasarkan Undang-Undang Republik Indonesia Nomor 20 Tahun 2008 tentang Usaha Mikro, Kecil, dan Menengah. Definisi menurut UU No. 20 Tahun 2008 tersebut adalah:

a. Usaha Mikro adalah usaha produktif milik orang perorangan dan/atau badan usaha perorangan yang memenuhi kriteria Usaha
Mikro sebagaimana diatur dalam Undang-Undang ini.

b. Usaha Kecil adalah usaha ekonomi produktif yang berdiri sendiri, yang dilakukan oleh orang perorangan atau badan usaha yang bukan merupakan anak perusahaan atau bukan cabang perusahaan yang dimiliki, dikuasai, atau menjadi bagian baik langsung maupun tidak langsung dari usaha menengah atau usaha besar yang memenuhi kriteria Usaha Kecil sebagaimana dimaksud dalam Undang-undang.

c. Usaha Menengah adalah usaha ekonomi produktif yang berdiri sendiri, yang dilakukan oleh orang perseorangan atau badan usaha yang bukan merupakan anak perusahaan atau cabang perusahaan yang dimiliki, dikuasai, atau menjadi bagian baik langsung maupun tidak langsung dengan Usaha Kecil atau usaha besar dengan jumlah kekayaan bersih atau hasil penjualan tahunan sebagaimana diatur dalam Undang-undang.

\section{Peran UMKM}

Sejarah perekonomian telah ditinjau kembali untuk mengkaji ulang peranan usaha skala mikro kecil dan menengah (UMKM). Beberapa kesimpulan, setidaktidaknya hipotesis telah ditarik mengenai hal ini. Pertama, pertumbuhan ekonomi yang sangat cepat sebagaimana terjadi di Jepang, telah dikaitkan dengan besaran sektor usaha kecil. Kedua, dalam penciptaan lapangan kerja di Amerika Serikat sejak perang dunia II, sumbangan UMKM ternyata tak bisa diabaikan (D.L. Birch, 1979 dalam Tambunan, 2013:3).

Negara-negara berkembang yang mulai mengubah orientasinya ketika melihat pengalaman-pengalaman di negara-negara tentang peranan dan sumbangsih UMKM dalam pertumbhan ekonomi. Usaha mikro kecil menengah (UMKM) memainkan peran-peran penting didalam pembangunan dan pertumbuhan ekonomi, tidak hanya di Negara-negara sedang berkembang (NSB), tetapi juga di 
Negara-negara maju (NM). Di NM, UMKM sangat penting tidak hanya karena kelompok usaha tersebut menyerap paling banyak tenaga kerja dibandingkan dengan usaha besar (UB). Di NSB, khususnya Asia, Afrika, dan Amerika Latin, UMKM juga berperan sangat penting khususnya dari perspektif kesempatan kerja dan sumber pendapatan bagi kelompok miskin, distribusi pendapatan dan pengurangan kemiskinan. Serta pembangunan ekonomi pedesaan (Tambunan, 2012:1). Tambunan menambahkan, dilihat dari kontribusinya terhadap Produk Domestik Bruto (PDB) dan Ekspor Non-Migas, khususnya produk-produk manufaktur, dan inovasi serta pengembangan teknologi, peran UMKM di NSB relative rendah, dan ini sebenarnya perbedaan yang paling mencolok dengan UMKM di NM.

\section{Karakteristik UMKM}

UMKM tidak saja berbeda dengan UB, tetapi ndidalam kelompok UMKM itu sendiri terdapat perbedaan karakteristik antara UMi, UK, dan UM dalam sejumlah aspek yang mudah dilihat sehari-hari di NSB, termasuk Indonesia. Aspek-aspek tersebut termasuk orientasi pasar, profil dan pemilik usaha, sifat dari kesempatan kerja di dalam perusahaan, sistem organisasi dan manajemen yang diterapkan di dalam usaha, derajat mekanisme di dalam proses produksi, sumber-sumber dari bahan baku dan modal, lokasi tempat usaha, hubunganhubungan eksternal, dan derajat keterlibatan perempuan sebagai pengusaha.

\section{Perkembangan UMKM}

Menurut database dari Menteri Negara Koperasi dan UKM (Menegkop \& UKM) dan Badan Pusat Statistik (BPS), pada tahun 1997 dalam Tambunan (2012:8), terdapat sekitar 39,7 juta usaha mikro kecil (UMK), dengan nilai penjualan rata-rata pertahun kurang dari Rp 1 Miliar per unit, atau sekitar 99,8 persen dari total unit usaha pada tahun itu. Pada tahun 1998, pada saat krisis ekonomi mencapai titik terburuknya dengan dampak negative yang sangat besar terhadap hampir semua sector ekonomi di Indonesia, banyak perusahaan dari berbagai skala usaha mengalami kebangkrutan atau mengurangi volume kegiatan secara drastic. Pada saat itu, Menegkop \& UKIM memperkirakan hampir 3 juta UMK berhenti berusaha, dan jumlah usaha menengah (UM) dan usaha besar (UB) yang tutup usaha, masing-masing sekitar 12,7 dan 14,2 persen dari jumlah unit masing-masing kelompok.

Lebih lanjut, Tambunan (2012:9) menjelaskan, pada tahun 2000, saat ekonomi Indonesia mulai pulih dari krisis ekonomi 1997/1998, tercatat ada sekitar 39,7 juta UMK, atau 99,85 persen dari jumlah perusahaan dari jumlah perusahaan berbagai skala di Indonesia. Pada tahun yang sama, ada sekitar 78,8 juta UM, dengan rata-rata nilai penjualan per tahun berkisar lebihy dari Rp 1 juta dan kurang dari Rp 50 miliar, atau 0,14 persen dari semua usaha yang ada. Pada tahun 2005, jumlah UMK tercatat sekitar 47 juta, sedangkan jumlah UM mencapai hampir 96 juta unit. Pada tahun 2006, jumlah UMK mencapai sekitar 99,77 persen dari jumlah usaha yang ada di Indonesia, sedangkan jumlah UM dan UB, masing-masing 0,01 dan 0,22 persen. Namu demikian, laju pertumbuhan unit usaha dari kelompok UM jauh lebih tinggi dibandingkan dengan UMK. Pada tahun 2008, jumlah populasi UMK dan UM (sebut saja UMKM) mencapai sekitar 52,3 jutab unit dan bertambah lagi menjadi 52,7 juta unit pada tahun 2009, atau 99,99 persen terhadap total unit usaha di Indonesia yang berjumlah 52, 769 juta unit usaha.

Dilihat dari kesempatan kerja, pada tahun 2006, UMK mempekerjakan 80.933.384 orang, atau 91,14 persen dari jumlah angkatan kerja yang bekerja. Jumlah ini meningkat dari 70.282.178 orang pada tahun 2003, atau laju pertumbuhan sebesar 15,15 persen. Sedangkan UM dan UB, masing-masing 4.483.109 dan 3.388.462 orang. Jumlah pekerja di UM dan UB tersebut masingmasing menurun dan meningkat dari 8.754.615 dan 438.198 orang (atau masing-masing dengan tingkat pertumbuhan secara bersamaan), UMKM 
mempekerjakan hampir 91 juta orang dibandingkan UB yang hanya sekitar 2,8 juta orang (Tambunan, 2012:10).

Salah satu ciri UMKM di Indonesia dan di negara berkembang lainya, adalah biasanya kelompok industri yang sama, berlokasi berdekatan satu sama lain di suatu wilayah. Pengelompokan secara geografis menurut kelompok ini, didalam literratur industry atau UMKM, disebut klaster. Di Indonesia, banyak kegiatan UMKM, khususnya UMK, yang tersebar di daerah-daerah memang sudah berlangsung turun-temurun, dan umumnya setiap daerah memiliki spesialisasi UMKM tersendiri.

\section{Kondisi UMKM di Indonesia}

Usaha Mikro Kecil dan Menengah telah tumbuh dan berkembang cepat dari waktu ke waktu. Perkembangan yang cukup pesat ini berdampak pada kompetisi yang semakin meningkat. Kompetisi yang meningkat cenderung menyebabkan tingkat keuntungan (rate of return) yang diperoleh UMKM mengarah pada keseimbangan. Bahkan pada kondisi tertentu, industri kecil yang tidak mampu berkompetisi akan tergusur dari persaingan usaha (Herawati, 2003:34).

Krisis ekonomi yang melanda Indonesia sejak pertengahan tahun 1997 lalu, yang diawali dengan krisis nilai tukar rupiah terhadap dolar AS dan krisis moneter telah mengakibatkan perekonomian Indonesia mengalami suatu resesi ekonomi cukup besar. Krisis ini sangat berpengaruh negatif terhadap hampir seluruh lapisan golongan masyarakat dan hampir semua kegiatan perekonomian di dalam negeri, tidak terkecuali kegiatan-kegiatan yang diakukan oleh usaha kecil dan menengah (Tambunan, 2002:11). Berkenaan dengan perubahan yang terjadi, secara fundamental penting bagi perusahaanuntuk mengevaluasi kembali strategi dan kinerjanya disesuaikan dengan kondisi yang ada, sehingga mampu membangun keunggulan kompetitifnya yang merupakan faktor kunci keberhasilan usaha untuk dapat mengikuti kemajuan dan perubahan persaingan yang terjadi dewasa ini.
Usaha mikro kecil dan menengah sering kali dipandang sebagai sebuah problem (Herawati, 2003:2). Terdapat berbagai alasan mengapa muncul pandangan seperti itu. Tinjauan pesrpektif kemampuan usaha mikro kecil dan menengah dianggap kurang berdaya. Sehingga pemerintah merasa perlu memberikan perhatian khusus. Perlindungan dan bantuan usaha nampaknya menjadi suatu keharusan, mengingat jumlah tenaga kerja yang terserap dalam sektor ini cukup besar. Upaya dalam mengatasi masalah tersebut harus menjadi agenda pembangunan yang pokok, harus dilandasi oleh strategi penguatan dan pemberdayaan yang tujuannya adalah memampukan juga memandirikan lapisan pengusaha kecil.

Pandangan dari perspektif lain, usaha mikro kecil dan menengah justru memiliki kinerja yang lebih baik dibandingkan usaha besar. Hal tersebut dapat diketahui dari kemampuannya dalam melunasi kewajiban pembayaran hutang. Hasil laporan Badan Penyehatan Perbankkan Nasional (BPPN) tahun 2000 dalam Yuli (2005:5) menyebutkan bahwa dari 97,6 persen nasabah bank pengutang adalah tergolong pengusaha kecil dan menengah. Hal ini diketahui dari besarnya nilai pinjaman yaitu rata-rata dibawah 5 miliyar. Sementara itu, sisanya adalah pengutang dari pengusaha besar.

Kemampuan usaha mikro kecil dan menengah untuk melakukan ekspor semakin meningkat, kendatipun krisis ekonomi belum menunjukkan perbaikan yang cukup signifikan. Pada tahun 2000, transaksi ekspor komoditi industri kecil diantaranya pangan, sandang, dan kerajinan mampu menjangkau sebesar 3,05 miliyar dollar AS, atau meningkat dari tahun sebelumnya. Sementara itu, hampir 60 persen dari produk domestik bruto (PDB) berasal dari kegiatan usaha mikro kecil dan menengah. Kondisi ini yang tidak jauh berbeda juga terjadi di masingmasing provinsi di Indonesia (Yuli, 2009:6).

\section{Konsep Pengembangan UMKM}

Menurut Danoko (2008:2), dalam upaya penumbuhan usaha kecil, perlu 
diketahui karakteristik serta permasalahan dan kendala yang dihadapi oleh usaha kecil. Pada umumnya, usaha kecil mempunyai ciri sebagai berikut:

1. Berbentuk usaha perorangan dan belum berbadan hukum

2. Aspek legalitas usaha lemah

3. Struktur organisasi bersifat sederhana dengan pembagian kerja yang tidak baku

4. Kebanyakan tidak memiliki laporan keuangan dan tidak melakukan pemisahan antara kekayaan pribadi dengan kekayaan perusahaan

5. Kualitas manajemen rendah dan jarang memiliki rencana usaha

6. Sumber utama modal adalah modal pribadi

7. Sumber daya manusia (SDM) terbatas

8. Pemilik memiliki ikatan batin yang kuat dengan perusahaan, sehingga seluruh kewajiban perusahaan juga menjadi kewajiban pemilik.

Kondisi tersebut berakibat kepada:

1. Lemahnya jaringan usaha serta keterbatasan kemampuan penetrasi dan diversifikasi pasar

2. Skala ekonomi terlalu kecil sehingga sukar menekan biaya

3. Margin keuntungan sangat tipis.

Pengembangan aliansi strategis pengusaha Indonesia menghadapi era pasar bebas dalam pembangunan ekonomi nasional sedang dan akan menghadapi berbagai perubahan fundamental yang berlangsung dengan cepat dan perlu kesiapan dari pelakunya. Menurut Kartasasmita (1996:1), yang dimaksud dengan perubahan fundamental tersebut adalah:

1. Terjadi di tingkat internasional yaitu proses globalisasi dengan perdagangan bebas dunia sebagai salah satu motor penggeraknya. Perubahan ini mempunyai dampak langsung pada perekonomian nasional dan usaha kecil nasional adalah globalisasi dan liberalisasi perdagangan. Globalisasi dan liberalisasi perdagangan berarti pasar dunia akan terbuka bagi produk-produk Indonesia, dan sebaliknya pasar domestik Indonesia pun akan makin terbuka pula bagi produk-produk internasional. Di pasar domestik, globalisasi menyebabkan terjadinya proses internasionalisasi sistem budaya dengan dampak langsung terhadap perilaku knsumsi masyarakat. Pergeseran pola konsumsi ini lepas dari preferensi masyarakat baik sebagai individu maupun sebagai bangsa, akan menggeser pua permintaan akan produk-produk nasional yang tidak memiliki ciri budaya internasional. Ditinjau dari sisi permintaan, konsumen akan membutuhkan barang dan jasa yang semakin beragam serta menuntut jaminan kualitas yang tinggi. Tuntutan konsumen yang semakin tinggi tersebut mendorong para pelaku ekonomi di dunia industri manufaktur dan jasa untuk menerjemahkan selera konsumen pada satu kepaduan produk (product integrity). Sementara itu, ditinjau dari sisi penawaran, teknologi berperan makin besar, dan mengubah pola produksi, terutama dengan berkembangnya teknologi informasi yang membuka kemungkonan-kemungkinan yang belum terlihat batas-batasnya. Konsep desain manufaktur dan perakitan serta rekayasa keteknikan akan mengikuti pola perkembangan yang makin terspesialisasi itu. Faktor nilai (value) aka makin dominan dan merupakan fenomena gobal karena tidak hanya menitikberatkan pada kualitas, tetapi juga pada ketersediaan waktu (time avability) dan tingkat limbah yang dihasilkan.

2. Perubahan fundamental kedua terjadi di dalam negeri, yaitu berlangsungnya transformasi struktur perekonomian nasional dan peningkatan pendapatan masyarakat yang diikuti oleh 
perubahan pola konsumsi masyarakat berkenaan dengan dinamika pembangunan ekonomi nasional itu sendiri, yaitu transformasi struktur perekonomian dari ekonomi tradisional ke ekonomi modern, dari ekonomi agraris ke ekonomi industri. Proses industrialisasi akan menghasilkan permintaan yang meningkat akan bahan-bahan baku dan barang-barang setengah jadi, serta komponen-komponen bagi industri pada berbagai tahapannya dari hulu ke hilir. Dengan demikian, permintaan akan berbagai jenis barang bukan hanya meningkat, tetapi akan semakin beragam. Di bidang jasa, juga terjadi proses yang sama, karena proses transformasi yang sedang terjadi juga menyangkut jasa-jasa yang akan makin penting perannya dalam struktur ekonomi yang modern. Permintaan akan jasa akan semakin besar, baik volume, jenis, maupun kualitasnya. Pembangunan ekonomi juga meningkatkan pendapatan dan kesejahteraan masyarakat, begitu pula dengan daya belinya. Hal ini berarti pasar domestik akan terus membesar dengan permintaan akan produk-produk yang makin tinggi kualitasnya, makin luas, dan makin banyak macamnya, serta makin canggih teknooginya. Perubahan-perubahan ini bersifat sangat mendasar, oleh karena itu menuntut perhatian kita bersama untuk melakukan langkah-langkah strategis sehingga perubahanperubahan yang terjadi justru menjadi peluang yang dapat dimanfaatkan oleh usaha kecil, yang jumlahnya sangat besar serta menjadi sandaran hidup sebagian besar rakyat Indonesia, untuk tumbuh dan berkembang secara alamiah, institusional, dan berkelanjutan. Kedua-duanya menghasilkan hal yang sama, yaitu memberikan kesempatan kepada dunia usaha nasional untuk berkembang dengan kecepatan tinggi, karena proses globalisasi itu sendiri berkembang dengan cepat. Untuk dapat memfaatkan kesempatan tersebut, terdapat syarat yang harus dipenuhi, yaitu (Kartasasmita, 1996:3):

\section{Konsep Pemasaran}

Manajemen merupakan proses perencanaan, mengorganisasikan dan pengawasan usaha-usaha para anggota organisasi dan penggunaan sumber daya organisasi lainnya agar mencapai tujuan yang telah ditentukan. Pemasaran adalah suatu proses sosial dan manajerial yang didalamnya individu dan kelompok mendapatkan apa yang mereka butuhkan dan inginkan dengan menciptakan, menawarkan dan mempertukarkan produk atau jasa yang bernilai dengan pihak lain (Kotler, 1997). Sedangkan manajemen pemasaran didefinisikan sebagai sebuah proses perencanaan, pengorganisasian, implementasi dan pengendalian aktivitasaktivitas pemasaran untuk memudahkan dan melancarkan ekspedisi secara efektif dan efisien (Ferel dalam Diana, 2003).

Kunci sukses pemasaran adalah selalu mendapatkan tempat yang cocok yang mewakili hasrat konsumen yang tidak terpenuhi dan memanfaatkan peluang itu secara agresif. Keberhasilan usaha pemasaran suatu perusahaan tergantung pada kemampuan manajemen untuk merencanakan secara strategis programprogram pemasaran dalam kerangka lingkungan perusahaan agar tujuan perusahaan dapat tercapai.

\section{Konsep Strategi Pemasaran}

Strategi pemasaran adalah strategi yang disatukan, luas, terintegrasi dan komprehensif yang dirancang untuk memastikan bahwa tujuan pemasaran bagi perusahaan dapat dicapai melalui pelaksanaan yang tepat oleh organisasi. Strategi pemasaran dapat didekati dengan konsep bauran pemasaran atau marketing mix (McCharty dalam Kotler, 1997). Bauran pemasaran merupakan kumpulan variabel yang terdiri dari 4P yaitu produk (product), harga (price), distribusi (place) dan promosi (promotion). 
Dalam formulasi strategi ada tiga tahap yang harus dilalui (David, 2002) yaitu: 1) tahap masukan (input stage), 2) tahap pemaduan (matching stage), 3) tahap pengambilan keputusan (decision stage). Pada tahap masukan, dilakukan eksplorasi informasi terhadap faktor-faktor lingkungan internal dan eksternal organisasi. Pada tahap pemaduan, dilakukan pemaduan antara sumberdaya dan kemampuan internal dengan faktorfaktor eksternal yang mempengaruhi organisasi. Sedangkan pada tahap pengambilan keputusan, diputuskan strategi

berdasarkan analisis yang telah dilakukan dan didukung oleh intuisi yang tepat sehingga strategi yang dihasilkan tidak bersifat kaku, melainkan adaptif terhadap perubahan yang terjadi dan disesuaikan dengan misi dan tujuan organisasi.

\section{Strategi Bauran Pemasaran}

Menurut Kotler (1997), bauran pemasaran adalah kiat pemasaran yang digunakan perusahaan untuk mencapai sasaran pemasaran dalam pasar sasaran. Bauran pemasaran merupakan kombinasi variabel atau kegiatan yang merupakan inti dari sistem pemasaran, dimana variabel tersebut dapat dikendalikan oleh perusahaan untuk mempengaruhi reaksi para pembeli atau konsumen (Assauri, 1999).

Berdasarkan pengertian ini, bauran pemasaran merupakan kombinasi terpadu dari variabel-variabel terkendali yang harus dilaksanakan secara tepat. Pelaksanaan bauran pemasaran secara umum harus diupayakan seimbang meskipun perencanaannya boleh berbeda sesuai dengan kondisi perusahaan dan lingkungannya masing-masing.

\section{Analisis Lingkungan Pemasaran}

Penerapan strategis pemasaran
suatu perusahaan harus
mempertimbangkan faktor-faktor yang
menentukan keberhasilan yang dapat
dicapai oleh perusahaan, yaitu faktor-
faktor internal yang merupakan kekuatan
dan kelemahan perusahaan seperti
teknologi yang dimiliki perusahaan,
sumberdaya keuangan dan identifikasi

merk. Adapun faktor-faktor eksternal ditentukan oleh industri dan lingkungan yang lebih luas. Faktor-faktor ini dapat berupa peluang maupun ancaman bagi perusahaan dan menentukan lingkungan persaingan bagi perusahaan, yaitu terdiri dari faktor sosial ekonomi, demografi, hukum dan pemerintahan.

\section{Analisis Lingkungan Internal}

\section{a. Pemasaran}

Pemasaran dapat diuraikan sebagai sebuah fungsi organisasi dan sebuah kelengkapan dari proses berkreasi, berkomunikasi, mengantarkan nilai kepuasan terhadap konsumen dan juga untuk menciptakan dan membina hubungan yang erat dengan konsumen sebagai cara perusahaan mendapatkan keuntungan bagi organisasi dan pemilik perusahaan5. Pemasaran sebagai sebuah proses kegiatan yang dipengaruhi oleh berbagai faktor sosial, budaya, ekonomi dan manajerial. Sehingga dalam perkembangannya tiap individu atau kelompok memuaskan

kebutuhan dan keinginan mereka dengan menciptakan, menawarkan dan menukarkan produk yang memiliki nilai.

b. Sumberdaya Keuangan

Kondisi keuangan sering dianggap sebagai tolak ukur dan cerminan keberhasilan perusahaan dari posisi bersaing dan daya tarik keseluruhan bagi investor. Menetapkan kekuatan keuangan dan kelemahannya sangat penting untuk merumuskan strategi secara efektif. Faktor-faktor keuangan sering mengubah strategi yang ada dan mengubah rencana implementasi (David, 2002).

c. Sumberdaya Manusia

Efektivitas setiap organisasi bergantung pada seberapa baik sumberdaya manusia dimanfaatkan. Kegunaan efektif mereka tergantung pada berbagai kebijakan dan praktek manajemen. Manajemen sumberdaya manusia perusahaan bertanggung jawab dalam menentukan kebijakan mengenai estimasi kebutuhan tenaga kerja, rekrutmen dan seleksi, pelatihan dan pengembangan, motivasi, kompensasi, disiplin dan pemberhentian.

d. Produksi 
Produksi adalah rangkaian proses untuk mengubah masukan dan menjadikannya barang dan jasa. Added value yang ingin dicapai sebuah perusahaan dalam proses produksi bertujuan untuk memuaskan kebutuhan konsumen, dengan penerapan efisiensi produksi yang tinggi, biaya yang rendah dan distribusi secara besar-besaran perusahaan dapat memperluas pasar dan keunggulan bersaing dalam industri yang bersangkutan.

\section{e. $R \& D$}

Penelitian dan pengembangan (research and development) produk adalah salah satu cara perusahaan mempertahankan konsumen. Dengan melakukan inovasi terhadap produknya, perusahaan dapat membedakan dirinya dengan pesaing dalam industri. Perubahan trend sebagai refleksi perubahan keinginan konsumen akan merangsang kreativitas industri untuk menciptakan sebuah produk baru yang akan memberikan kepuasan terhadap konsumen mereka. Kemajuan teknologi akan mendorong kualitas produk yang dapat ditawarkan perusahaan untuk dapat terus memantapkan posisinya dalam industri

\section{Analisis Lingkungan Eksternal}

Menurut Glueck dan Lawrence (1996), lingkungan eksternal dapat dipandang sebagai lima sektor penting yaitu: sosioekonomi, teknologi, pemasok, pesaing dan pemerintah.

\section{a. Sektor Sosioekonomi}

Sektor sosioekonomi terdiri dari faktor ekonomi, demografi, dan sosial yang akan membantu atau menghambat perusahaan untuk mencapai tujuannya. Faktor-faktor yang umumnya dianalisis dalam lingkungan pemasaran adalah tahap siklus bisnis, inflasi dan deflasi, kebijakan keuangan, kebijakan fiskal, dan neraca pembayaran (Glueck dan Lawrence, 1996). Terdapat beberapa kondisi penting dalam faktor demografi yang dapat mempengaruhi lingkungan pemasaran. Kondisi tersebut terutama disebabkan oleh adanya jumlah penduduk dan distribusi umur penduduk. Karena populasi penduduklah yang membentuk sebuah pasar dan merangsang perusahaan untuk tumbuh dan berkembang untuk dapat memasarkan produk sebagai cerminan permintaan yang ada di dalamnya. Faktor sosial erat kaitannya dengan penilaian dan sikap orang baik konsumen maupun karyawan yang dapat mempengaruhi strategi. Faktor sosial yang mempengaruhi suatu perusahaan adalah kepercayaan, nilai, sikap, opini dan gaya hidup (Pearce dan Robinson, 1997)

b. Sektor Teknologi

Perubahan dalam bidang teknologi sangat berpengaruh terhadap keadaan produk barang dan jasa. Kecepatan perubahan teknologi yang diterima antara masing-masing sektor mungkin tidak akan sama. Kecenderungan-kecenderungan dalam teknologi, kesempatan inovasi yang tidak terbatas, anggaran penelitian dan pengembangan yang bervariasi dan regulasi yang meningkat akibat perubahan teknologi (Kotler, 1997)

c. Sektor Pemasok

Pemasok memiliki peran sebagai penyedia bahan baku bagi perusahaan, yang meliputi bahan mentah maupun bahan jadi dan setengah jadi. Pemasok memiliki beberapa kekuatan relatif yang dapat mempengaruhi perusahaan dalam menetapkan strategi yang digunakan. Porter (1995), menyatakan bahwa kekuatan masing-masing pemasok bergantung pada sejumlah karakteristik situasi pasarnya dan pada tingkat kepentingan relatif penjualan atau pembeliannya dalam industri tersebut dibandingkan dengan keseluruhan bisnisnya.

d. Sektor Pesaing

Sifat dan derajat persaingan dalam suatu industri bergantung pada lima kekuatan atau faktor-faktor yaitu ancaman pendatang baru, daya tawar-menawar pembeli, daya tawar-menawar pemasok, ancaman produk subtitusi dan persaingan diantara anggota industri (Porter, 1995). Untuk menyusun rancangan strategi menghadapi kekuatan-kekuatan ini, suatu perusahaan harus memahami bagaimana cara kerja kekuatan-kekuatan tersebut dalam industri dan bagaimana pengaruh 
mereka terhadap perusahaan dalam suatu industri tertentu.

\section{e. Sektor Pemerintah}

Tindakan pemerintah sangat berpengaruh terhadap berbagai pilihan strategi yang dapat meningkatkan peluang maupun hambatan usaha. Keuntungan ekonomi merupakan salah satu alasan bagi pemerintah untuk memberikan bantuan kepada perusahaan-perusahaan, di samping alasan keamanan, tenaga kerja dan lainnya (Swastha dalam Diana, 2003). Bantuan tersebut berupa subsidi, proteksi, pembelian dalam jumlah besar serta kebijakan yang mendukung bisnis perusahaan.

\section{Teori Perilaku Konsumen}

"Consumer behavior is defined as the acts of individuals directly involved in obtaining and using economic good services including the decision process that precede and determine these acts" James F. Engel et.al (1968: 8).

Perilaku konsumen didefinisikan sebagai tindakan-tindakan individu yang secara langsung terlibat dalam usaha memperoleh dan menggunakan barangbarang jasa ekonomis termasuk proses pengambilan keputusan yang mendahului dan menentukan tindakan-tindakan tersebut.

Langkah-langkah pengambilan keputusan pembelian seorang konsumen. Keputusan membeli atau mengkonsumsi suatu produk dengan merk tertentu akan diawali oleh langkah-langkah sebagai berikut:

1. Pengenalan kebutuhan
Pengenalan kebutuhan muncul
ketika konsumen menghadapi suatu masalah yaitu suatu keadaan dimana terdapat perbedaan antara keadaan yang diinginkan dan keadaan yang sebenarnya terjadi. Kebutuhan harus diaktifkan terlebih dahulu sebelum ia bisa dikenali. Ada beberapa faktor yamg mempengaruhi pengaktifan kebutuhan yaitu: waktu, perubahan situasi, pemilikan produk, konsumsi produk, perbedaan individu, pengaruh pemasaran.

\section{Pencarian informasi}

Pencarian informasi mulai dilakukan ketika konsumen memandang bahwa kebutuhan tersebut bisa dipenuhi dengan membeli dan mengkonsumsi suatu produk. Pencarian informasi bisa melalui informasi internal maupun eksternal. Faktor-faktor yang mempengaruhi pencarian informasi adalah (a) faktor resiko produk (keuangan, fungsi, psikologis, waktu, sosial, fisik), (b) faktor karakteristik konsumen (pengetahuan dan pengalaman konsumen, kepribadian dan karakteristik demografik), (c) faktor situasi (waktu yang tersedia untuk belanja, jumlah produk yang tersedia, lokasi toko, ketersediaan informasi, kondisi psikologis konsumen, resiko sosial dari situasi, tujuan belanja).

\section{Evaluasi alternatif}

Evaluasi alternatif adalah proses mengevaluasi pilihan produk dan merk dan memilihnya sesuai dengan yang diinginkan konsumen.

\section{Tindakan pembelian}

Setelah menentukan pilihan produk, maka konsumen akan melanjutkan proses berikutnya, yaitu melakukan tindakan pembelian produk atau jasa tersebut.

\section{Pengkonsumsian suatu produk.}

Untuk mengetahui konsumsi produk yang lebih mendalam, maka seorang pemasar harus mengetahui 3 hal yaitu: frekuensi konsumsi, jumlah konsumsi dan tujuan konsumsi.

\section{Faktor individu}

\section{Motivasi Dan Kebutuhan}

Motivasi muncul karena adanya kebutuhan yang dirasakan oleh konsumen. Kebutuhan sendiri muncul karena konsumen merasakan ketidaknyamanan (state of tension) antara yang seharusnya dirasakan dengan yang sesungguhnya dirasakan. Kebutuhan yang dirasakan tersebut mendorong seseorang untuk melakukan tindakan memenuhi kebutuhan tersebut. Inilah yang disebut dengan MOTIVASI. Seperti contoh adanya rasa haus dan lapar mendorong seseorang untuk mencai makanan dan minuman. Teori Motivasi McClelland 
David McClelland mengembangkan suatu teori motivasi. Teori ini menyatakan bahwa ada tiga kebutuhan dasar yang memotivasi seorang individu untuk berperilaku yaitu kebutuhan untuk sukses (Needs for Achievement), kebutuhan untuk afiliasi (Needs for Affiliation) dan kebutuhan kekuasaan (Needs for Power).

Kebutuhan yang dirasakan oleh konsumen (felt need) bisa dimunculkan dari faktor luar konsumen seperti aroma makanan $\square$ orang jadi ingin makan, iklan dan komunikasi pemasaran $\square$ orang yang tidak rencana beli jadi membeli. Selain dari luar konsumen juga ada faktor dari dalam diri konsumen sendiri (fisiologis) atau innate needs misal rasa lapar, haus (makanan), air, udara, pakaian rumah atau seks. Kebutuhan ini juga disebut dengan primary needs dimana produk tersebut dibutuhkan untuk mempertahankan hidupnya.

Disamping kebutuhan primer juga ada kebutuhan sekunder/motif yaitu kebutuhan yang diciptakan (acquired needs) adalah kebutuhan yang muncul sebagai akibat reaksi konsumen terhadad lingkungan dan budayanya. Dimana kebutuhan ini bersifat psikologis karena berasal dari subjektif konsumen. Misalnya rumah adalah kebutuhan primer tapi karena ingin dipandang sebagai orang sukses dan mampu sehingga ia memilih lokasi dan bentuk rumah yang bergengsi.

Kebutuhan yang diarasakan/felt needs seringkali dibedakan berdasarkan kepada manfaat yang diharapkan dari pembelian dan dan penggunaan produk. Pertama adalah kebutuhan utilitarian yang mendorong orang membeli produk karena manfaat fungsional dan karakteristik objektif dari produk tersebut. Misalnya obeng $\square$ memudahkan dalam membuka dan memasang kembali mur pada peralatan. Yang kedua kebutuhan ekspresive atau hedonik $\square$ psikologis seperti rasa puas, gengsi , emosi, dan perasaan subjektif lainnya. Misalnya konsumen yang sering memakai dasi di kantor. Dasi tidak memberikan manfaat fungsional tetapi memberikan manfaat estetika dan tuntutan sosial.

Maslow mengemukakan lima kebutuhan manusia berdasarkan tingkat kepentingannya mulai dari yang paling rendah, yaitu kebutuhan biologis, kebutuhan rasa aman, kebutuhan social, kebutuhan ego, kebutuhan aktualisasi diri. Menurut teori Maslow, manusia berusaha memenuhi kebutuhan tingkat rendahnya terlebih dahulu sebelum memenuhi kebutuhan yang lebih tinggi/Hirarki Kebutuhan Manusia (Maslow's Hierarchy of Needs).

\section{Kepribadian Dan Gaya Hidup}

Tidak ada dua manusia yang persis sama dalam sifat atau kepribadiannya, masing-masing memiliki karakteristik yang unik yang berbeda satu sama lain. Inilah yang disebut sebagai kepribadian manusia. Memahami kepribadian konsumen adalah penting bagi pemasar. Karena kepribadian bisa terkait dengan perilaku konsumen. Perbedaan dalam kepribadian konsumen akan mempengaruhi perilakunya dalam memilih atau membeli produk, karena konsumen akan membeli barang yang sesuai dengan kepribadiannya.

\section{Pengetahuan Konsumen \\ Pengetahuan konsumen adalah} semua informasi yang dimiliki oleh konsumen mengenai berbagai macam produk dan jasa serta pengetahuan lainnya yang terkait dengan produk dan jasa tersebut dan informasi yang berhubungan dengan fungsinya sebagai konsumen. Pengetahuan konsumen akan mempengaruhi keputusan pembelian. 3 kategori pengetahuan konsumen menurut Mowen dan Minor: Pengetahuan obyektif, pengetahuan subyektif dan informasi mengenai pengetahuan lainnya. Engel, Blackwell dan Miniard membagi pengetahuan konsumen ke dalam tiga macam yaitu

1. Pengetahuan Produk

a. kategori produk

b. merk

c. terminologi produk

d. atribut atau fitur produk

e. harga produk

f. kepercayaan produk

2. Pengetahuan pembelian

a. pengetahuan tentang toko

b. lokasi produk didalam toko 
c. penempatan produk yang sebenarnya didalam toko

\section{Faktor lingkungan}

\section{Budaya Dan Demografi}

Budaya merupakan suatu kepercayaan, nilai-nilai dan kebiasaan yang dipelajari seseorang, yang dapat mengarahkan seseorang tersebut dalam menggunakan suatu barang atau jasa. Kepercayaan, nilai-nilai dan kebiasaan itu dapat muncul bila seseorang melakukan interaksi, hubungan dan saling mempengaruhi dalam berperilaku. Unsurunsur budaya antara lain:
a. kepercayaan
b. nilai
c. norma
d. kebiasaan
e. larangan
f. mitos
g. symbol

Unsur-unsur budaya tersebut dapat mempengaruhi pengkonsumsian suatu produk dan jasa, sebagai salah satu contoh: pada saat panen raya, petani menggelar syukuran tanda keberhasilan dalam berproduksi, sehingga konsumsi terhdap beras, daging dan sayur-sayuran akan meningkat.

Budaya dapat dipelajari karena sangat kental di kehidupan sosialnya, antara lain:
a. prestasi dan sukses pekerjaan
b. aktifitas sehari-hari
c. efisiensi dan kepraktisan dalam beraktifitas
d. kemajuan keluarga
e. kesenangan pada materi
f. individualisme
g. kebebasan
h. penyesuaian eksternal
i. perikemanusiaan
j. kebugaran dan kesehatan
k. pergaulan, dII

Karakteristik Demografi dan Sub budaya Karakteristik demografi menunjukkan identitas seseorang bisa berdasarkan usia, agama, suku bangsa, pendapatan, jenis kelamin, status pernikahan, pekerjaan, lokasi geografis, dan lain-lain. Sub budaya merupakan kelompok budaya berbeda sebagai segmen yang dapat dikenali dalam masyarakat tertentu yang lebih luas dan lebih kompleks.

\section{Keluarga}

Keluarga merupakan dua orang atau lebih yang dikaitkan oleh hubungan darah, perkawinan, atau pengadopsiam yang tinggal bersama-sama atau terpisah. Fungsi pokok keluarga adalah adanya proses sosialisasai.

Model sederhana mengenai proses sosialisasi : Peranan dalam pengambilan keputusan keluarga antara lain:

a. sebagai Influencer, para memberikan pengaruh pada anggota keluarga lain untuk mengambil keputusan dalam pembelian atau tidak membeli suatu produk.

b. sebagai gate keeper, para anggota keluarga yang mengontrol arus informasi

c. sebagai decision, anggota keluaga yang menentukan membeli atau tidak suatu produk

d. sebagai buyer, anggota keluarga yang dengan nyata melakukan pembelian

e. sebagai preparer, anggota yang mengubah produk mentah menjadi bentuk yang bisa dikonsumsi

f. sebagai user, anggota keluarga yang menggunakan produk tersebut

g. sebagai maintancer, anggota keluarga yang merawat atau memperbaiki produk

h. sebagai organizer, anggota keluarga yang mengatur apakah produk tersebut bisa dimulai dipakai atau dibuang atau dihentikan

Kelompok Referensi 
Kelompok adalah dua atau lebih yang berinteraksi untuk mencapai sasaran perorangan maupun bersama, seperti kelompok persahabatan, kelompok bekajar, kelompok kerja, kelompok/masyarakat maya, kelompok aksi konsumen dan lain-lain.

Adapun definisi dari kelompok rujukan atau referensi adalah setiap orang atau kelompok yang dianggap sebagai dasar pembandingan bagi seseorang dalam membentuk nilai dan sikap umum/khusus atau pedoman khusus bagi perilaku.

Faktor yang berdampak pada pengaruh kelompok rujukan :

a. informasi dan pengalaman

b. kredibilitas, daya tarik dan kekuatan kelompok rujukan

Para pemasar tertarik pada kemampuan kelompok rujukan untuk mengubah sikap dan perilaku konsumen dengan mendorong timbulnya kesesuaian. Untuk dapat mempunyai pengaruh tersebut, kelompok rujukan harus melakukan hal-hal berikut ini.
a. Memberitahukan atau mengusahakan agar orang produk/merk khusus menyadari adanya suatu
b. Memberikan kesempatan pada individu untuk membandingkan pemikirannya sendiri dengan sikap dan perilaku kelompok
c. Mempengaruhi individu untuk mengambil sikap dan perilaku yang sesuai dengan norma- norma kelompok
d. Membenarkan keputusan untuk memakai produk-produk yang sama dengan kelompok

Daya tarik kelompok rujukan dalam pemasaran melalui:
a. daya tarik selebriti
b. daya tarik tenaga ahli
c. daya tarik orang biasa
d. daya tarik juru bicara eksekutif dan karyawan
e. daya tarik kelompok rujukan lain

\section{Kelas Sosial}

Kelas sosial merupakan pembagian anggota masyarakat ke dalam suatu hirarki status kelas sosial yang berbeda, sehingga para anggota setiap kelas secara relatif mempunyai status yang sama dan para anggota kelas lainnya mempunyai status yang lebih tinggi atau lebih rendah.

Pendekatan sistematis untuk mengukur kelas social tercakup dalam berbagai kategori yang luas, berikut ini:

a. ukuran subyektif (kelas bawah, menengah-bawah, menengahatas, atas)

b. ukuran reputasi

c. ukuran obyektif terdiri dari variabel demografis atau sosioekonomis (pekerjaan, pendidikan, penghasilan, konsumsi, tabungan, hutang dan lain-lain)

Adapun pembagian Profil kelas sosial:

Kelas atas-atas (perkumpulan country club)

a. Sejumlah kecil keluarga yang telah betul-betul mapan

b. Menjadi anggota berbagai club yang terbaik dan mensponsori berbagai peristiwa amal yang besar

c. Bertindak sebagai pengawas berbagai perguruan timggi dan rumah sakit setempat

d. Para dokter dan pengacara yang terkemuka

e. Mungkin pemimpin berbagai lembaga keuangan yang besar, pemiliki berbagai perusahaan besar yang sudah lama berdiri

f. Sudah terbiasa kaya, karena itu tidak membelanjakan uang secara mencolok

Kelas atas-bawah (orang kaya baru)

a. Tidak terlalu diterima oleh lapisan masyarakat atas

b. Merupakan orang kaya baru

c. Eksekutif perusahaan yang sukses

d. Pengguna kekayaan baru yang mencolok 
Kelas menengah-atas
a. Tidak mempunyai status keluarga maupun kekayaan yang luar biasa
b. Berorientasi kepada karier
c. Para professional muda yang sukses, manajer perusahaan dan pemilik perusahaan

Kebanyakan adalah tamatan perguruan tinggi, banyak yang mempunyai gelar S2 atau S3

a. Aktif dalam berbagai kegiatan professional, masyarakat dan sosial

b. Mempunyai minat yang kuat dalam memperoleh hal-hal yang lebih baik dalam hidup

c. Rumah mereka adalah symbol dari prestasi mereka

d. Konsumsi sering mencolok

e. Sangat berorientasi pada anak

Kelas menengah-bawah

a. Terutama para pekerja kantor yang tidak mempunyai kedudukan memimpin dan para pekerja pabrik yang bergaji besar

b. Ingin mendapat penghargaan dan diterima sebagai warga negara yang baik

c. Menginginkan anak-anak mereka berkelakuan baik

d. Cenderung menjadi pengunjung tempat ibadah yang rajin dan sering terlibat dalam berbagai kegiatan keagamaan

e. Lebih menyukai penampilan yang rapi dan bersih serta cenderung mengikuti mode atau gaya mutakhir

f. Merupakan pasar yang utama untuk berbagai produk yang praktis

Kelas bawah-atas

a. Segmen kelas sosial yang terbesar

b. Pekerja pabrik yang tekun

c. Berjuang untuk memperoleh rasa aman d. Memandang pekerjaan sebagai alat untuk membeli kesenangan

e. Menginginkan anak untuk berperilaku sopan

f. Penerima upah yang tinggi dalam kelompok ini sehingga belanja menurutkan kata hati

g. Tertarik pada barang-barang yang dapat meningkatkan kenikmatan waktu senggang

h. Para suami secara tipikal mempunyai citra diri "macho" yang kuat

i. Para pria adalah penggemar olah raga, perokok berat, peminum bir

Kelas bawah-bawah

a. Berpendidikan rendah, para pekerja yang tidak trampil

b. Sering tidak bekerja

c. Anak-anak sering diperlakukan tidak baik

d. Cenderung hidup dengan biaya dari hari ke hari

\section{Faktor Psikologis}

Pengolahan Informasi / Persepsi

Apa yang didengar oleh telinga, apa yang dilihat oleh mata dan apa yang dicium oleh hidung, itulah yang disebut dengan stimulus. Tidak semua stimulus tersebut semua kita ingat dan simpan dalam ingatan kita, karena kita sebagai konsumen melakukan proses pengolahan informasi. Stimulus bisa berbentuk produk, nama merk, kemasan, iklan, nama produsen. Engel, Blackwell and Miniard menyatakan ada 5 tahap pengolahan informasi yaitu
a. Pemaparan (exposure) pemaparan stimulus, yang menyebabkan konsumen menyadari stimulus tersebut melalui pancainderanya. b. Perhatian (attention)
kapasitas pengolahan yang
dialokasikan konsumen terhadap stimulus yang masuk
c. Pemahaman (comprehension) 
interpretasi terhadap makna stimulus

d. Penerimaan (acceptance) dampak persuasif stimulus kepada konsumen

e. Retensi $\square$ pengalihan makna stimulus \& persuasi ke ingatan jangka panjang

Keterlibatan

Keterlibatan adalah status motivasi yang menggerakkan serta mengarahkan proses kognitif dan perilaku konsumen pada saat mereka membuat keputusan. Contoh: konsumen akan membeli suatu produk akan menghabiskan lebih banyak waktu dan tenaga untuk berkunjung ke beberapa toko atau bertanya pada lebih banyak pramuniaga. diajukan ke konsumen untuk melihat tinggi rendahnya keterlibatan terhadap suatu produk, antara lain:

a. Saya akan tertarik membaca mengenai jagung Bisi 1

b. Saya akan membaca artikel mengenai segala macam yang berhubungan dengan jagung Bisi 1

c. Saya telah membandingkan jagung Bisi 1 dengan jagung merk lain

d. Saya memperhatikan iklan jagung Bisi 1

e. Saya membicarakan jagung Bisi 1 ini dengan petani lain

f. Saya meminta nasehat pada petani lain mengenai keunggulan Bisi 1

g. Saya menghabiskan waktu lama untuk berkunjung ke kios-kios pertanian

\section{Proses Pembelajaran Konsumen}

Sebagai seorang konsumen baik dari anak sampai orang tua melakukan proses belajar. Seorang konsumen yang menyukai produk tertentu, memilih produk tertentu dan loyal terhadap merek tertentu, merupakan hasil dari suatu proses belajar konsumen. Pemasar perlu memahami bagaimana konsumen belajar, karena pemasar berkepentingan untuk mengajarkan konsumen agar konsumen bisa mengenali iklan produknya, mengingatnya, menyukainya dan membeli produk yang dipasarkan.

Belajar adalah perubahan perilaku yang relatif permanen yang diakibatkan oleh pengalaman. Syarat proses belajar:

a. Motivasi $\square$ daya dorong dari dalam diri konsumen, muncul karena adanya kebutuhan

b. Isyarat $\square$ stimulus yang mengarahkan motivasi tersebut. Iklan, kemasan, harga dan produk display adalah stimulus/isyarat yang mempengaruhi konsumen untuk memenuhi kebutuhannya.

c. Respon $\square$ reaksi terhadap isyarat.

d. Pendorong atau penguat $\square$ sesuatu yang meningkatkan

kecenderungan seorang konsumen untuk berperilaku pada masa datang karena adanya isyarat atau stimulus.

Contoh: Pengalaman pertama jaga malam agar tidak kantuk ia coba minum Kopi Nescafe dan ternyata sangat ampuh. Pengalaman keduanya tentu dia akan meminum Kopi Nescafe kembali. Begitu ada iklan Nescafe, maka iklan itu menjadi pendorong baginya untuk membeli kopi Nescafe.

\section{METODE PENELITIAN}

\section{Pendekatan Penelitian}

Penelitian ini adalah penelitian kasus. Kasus yang dipilih adalah Produsen sandal Desa Pragaan Daya. Pemilihan lokasi ini dilakukan secara sengaja (purposive) dengan mempertimbangkan bahwa produsen sandal Desa Pragaan Daya merupakan satu-satunya perusahaan sandal di kecamatan Pragaan. Selain itu produsen sandal ini telah berkembang dengan sistem administrasi yang mampu menyediakan data yang baik. Penelitian ini 
dilaksanakan pada bulan Maret-April 2018 untuk mengumpulkan data yang diperlukan.

Studi kasus adalah sebuah penyelidikan empiris yang menginvestigasi fenomena kontemporer dalam konteks kehidupan nyata, khususnya ketika batas antara fenomena dan konteks tidak begitu jelas (Yin, 2011).

\section{Analisis Dan Pembahasan}

Untuk setiap transaksi pembayaran produk, sistem pembayaran yang dilakukan dengan cara Letter of Credit (L/C) kepada pihak yang ditentukan oleh perusahaan dengan jangka waktu penerimaannya yaitu satu bulan setelah pengiriman barang. Pada produsen sandal, yang menetapkan harga jual adalah bagian pemasaran, bagian keuangan, bagian produksi. Kebijakan harga yang dipergunakan pada perusahaan adalah:

1. Kebijakan harga berorientasi pada biaya Penetapan harga jual berdasarkan harga pokok ditambah presentasi keuntungan yang diharapkan.

2. Kebijakan harga berorientasi pada harga jual yang berbeda Penetapan harga jual berdasarkan situasi dan kondisi pasar

3. Kebijakan harga berorientasi pada harga jual bersaing, yaitu menetapkan harga lebih tinggi, lebih rendah, atau sama dengan pesaing

Dalam memasarkan produknya, produsen sandal desa Pragaan Daya melakukan promosi penjualan melalui kegiatan:

a. Menawarkan langsung ke calon pembeli melalui presentasi produk, lebih ditujukan untuk pelanggan korporasi atau instansi pemerintah sebagai upaya untuk mengenalkan produk baru.

b. Menawarkan produk kepada calon pembeli melalui internet, yaitu dengan menggunakan facebook.

c. Pembuatan brosur atau leaflet yang berupa contoh gambar model dari produk yang dihasilkan perusahaan.

Kegiatan promosi berupa penawaran produk seperti di atas dirasakan perusahaan telah mencukupi. Perusahaan memiliki pelanggan tetap yang umumnya telah menjalin hubungan dengan perusahaan, sehingga perusahaan tidak mengeluarkan biaya yang besar untuk promosi dan pemasaran produknya. Kegiatan promosi dengan menggunakan leaflet dilakukan perusahaan bersamaan dengan presentasi langsung (menawarkan langsung) dengan membagikan leaflet tersebut kepada calon pembeli yang telah menggunakan produk perusahaan. Tujuan pemberian leaflet adalah mempromosikan produk terbaru dari perusahaan. Selama ini pemasaran dan promosi perusahaan kepada calon pembeli dirasakan belum menyasar pasar potensial di luar yang jauh lebih besar, dimana perusahaan lebih memfokuskan usaha pemasaran pada sedikit pembeli produk perusahaan yang tidak lain merupakan pelanggan perusahaan.

\section{Analisis SWOT}

Analisis SWOT adalah identifikasi berbagai faktor secara sistematis untuk merumuskan strategi perusahaan (Rangkuti, 2001). Analisis ini didasarkan pada logika yang dapat memaksimalkan kekuatan (strengths) dan peluang (opportunities) namun secara bersamaan dapat meminimalkan kelemahan (weaknesses) dan ancaman (threats). Analisis SWOT merupakan cara sistematis untuk mengidentifikasikan keempat faktorfaktor tersebut dan strategi yang menggambarkan kecocokan paling baik di antara mereka (Pearce dan Robinson, 1997). Dengan demikian perencanaan strategi harus menganalisis faktor-faktor strategis perusahaan (kekuatan, kelemahan, peluang dan ancaman) dalam 
kondisi yang ada pada saat ini. Faktorfaktor strategis perusahaan disusun dalam matriks SWOT, yang menggambarkan secara jelas bagaimana peluang dan ancaman eksternal yang dihadapi perusahaan dapat disesuaikan dengan kekuatan dan kelemahan yang dimilikinya. Matriks ini dapat menghasilkan empat sel kemungkinan alternatif strategi (Rangkuti, 2001).

\section{Kekuatan}

Merupakan sumberdaya, ketrampilan atau keunggulan-keunggulan lain relatif terhadap pesaing dan kebutuhan pasar yang dilayani atau ingin dilayani oleh perusahaan. Kekuatan adalah kompetensi khusus (distinctive competence) yang memberikan keunggulan komparatif bagi perusahaan di pasar. Kekuatan dapat terkandung dalam sumberdaya keuangan, citra, kepemimpinan pasar, hubungan pembeli dengan pemasok dan faktor-faktor lain (Pearce dan

Robinson, 1997).

\section{Kelemahan}

Pearce dan Robinson, (1997) mendefinisikan kelemahan sebagai keterbatasan atau kekurangan dalam sumberdaya, ketrampilan dan kapabilitas yang dapat menghambat kinerja efektif perusahaan. Sumber-sumber kelemahan tersebut dapat meliputi fasilitas, sumberdaya keuangan, kapabilitas manajemen, ketrampilan pemasaran dan citra merk.

\section{Peluang}

Peluang merupakan situasi penting yang menguntungkan dalam lingkungan perusahaan (Pearce dan Robinson, 1997). Perkembangan trend merupakan salah satu sumber peluang. Identifikasi segmen pasar yang terabaikan, perubahan situasi persaingan atau peraturan, perubahan teknologi serta membaiknya hubungan antara pembeli dengan pemasok dapat memberikan peluang bagi perusahaan.

\section{Ancaman \\ Ancaman adalah situasi penting yang tidak menguntungkan dalam}

lingkungan perusahaan (Pearce dan Robinson, 1997). Ancaman merupakan penggangu utama bagi posisi perusahaan. Masuknya pesaing baru, lambatnya pertumbuhan pasar, meningkatnya kekuatan tawar-menawar pembeli atau pemasok utama, perubahan teknologi serta peraturan baru atau yang direvisi dapat menjadi ancaman bagi keberhasilan perusahaan.

\section{Perumusan Strategi Pemasaran Terpilih}

Perumusan strategi pemasaran
terpilih dapat dilakukan setelah sebelumnya dilakukan analisis lingkungan internal dan eksternal perusahaan dan kemudian dilanjutkan dengan analisis matriks IFE dan EFE yang menghasilkan faktor-faktor internal (kekuatan dan kelemahan) dan faktor-faktor eksternal perusahaan (peluang dan ancaman). Posisi perusahaan di industri dapat diketahui melalui matriks IE yang memetakan perusahaan dalam kuadran sesuai dengan total skor terbobot yang di peroleh dari matriks IFE dan EFE. Alat analisis yang digunakan dalam menentukan hasil akhir strategi pemasaran terpilih adalah matris SWOT dan QSPM.

\section{Analisis Matriks I-E (Internal-External)}

Berdasarkan matriks IFE yang menunjukkan bahwa perusahaan berada pada posisi rata-rata yang ditunjukkan dengan skor sebesar 2,846. sedangkan pada matriks EFE menghasilkan skor 2,823 yang berarti perusahaan memiliki faktor eksternal di atas rata-rata. Apabila masing-masing nilai tersebut dipetakan dalam matriks I-E, maka diperoleh posisi perusahaan saat ini, yaitu pada sel $\mathrm{V}$. Pada sel ini perusahaan berada pada kondisi internal rata-rata dan respon perusahaan terhadap faktor-faktor eksternal yang dihadapinya tergolong sedang. Strategi yang tepat untuk perusahaan yang berada pada sel $\mathrm{V}$ adalah strategi pertahankan dan pelihara (hold and maintain). Strategi penetrasi pasar dan strategi pengembangan produk 
merupakan dua strategi yang paling banyak dilakukan untuk sel ini. Posisi perusahaan pada matriks I-E ditunjukkan pada gambar 4. Penetrasi pasar merupakan pencarian pangsa pasar yang lebih besar atau peningkatan pangsa pasar produk yang sudah ada melalui peningkatan usaha pemasaran. Jika Produsen sandal desa Pragaan Daya ingin melakukan strategi penetrasi pasar, maka yang harus dilakukan perusahaan adalah melakukan pengembangan atau perluasan pasar dengan memperluas cakupan area (daerah) pemasaran yang telah ada sebelumnya dan kerjasama dengan berbagai pihak yang dirasa dapat mendukung proses pengembangan atau perluasan pasar tersebut. Adanya pasar potensial yang belum dimasuki perusahaan menjadikan strategi ini tepat untuk diimplementasikan. Strategi penetrasi pasar yang lain dapat dilakukan dengan cara meningkatkan kegiatan promosi baik melalui periklanan, promosi penjualan, maupun pemberian merchandising kepada para konsumen (customer).

Strategi pengembangan produk dapat perusahaan lakukan antara lain melalui peningkatan penjualan dengan memperbaiki dan meningkatkan mutu produk dan jasa (layanan purna jual, potongan harga, customer service dan sebagainya) yang sudah ada atau mengembangkan sesuatu yang baru. Pada strategi ini, Produsen sandal desa Pragaan Daya dapat terus melakukan inovasi pada produk yang dihasilkannya atau yang akan diproduksi, transfer teknologi canggih paling baru untuk proses produksi, meningkatkan standar mutu hasil produk, serta mengimplementasikannya.

Analisis Matriks SWOT (Strengths, Weaknesses, Opportunities, and Threats)

Matriks SWOT memberikan berbagai alternatif seperti halnya matriks IE (Internal-External). Matriks SWOT memformulasikan strategi berdasarkan gabungan antara faktor eksternal dan internal. Empat strategi utama yang digunakan adalah menggunakan kekuatan untuk memanfaatkan peluang (strategi SO), memanfaatkan kekuatan untuk mengatasi ancaman (strategi ST), memperkecil kelemahan dengan memanfaatkan peluang (strategi WO), memperkecil kelemahan juga sekaligus mengantisipasi ancaman (strategi WT). Analisis ini menggunakan data yang telah diperoleh dari matriks IFE dan matriks EFE pada tahap masukan (the input stage) sebelumnya. 
ISSN 1412-2936

EISSN 2549-7308

\begin{tabular}{|c|c|c|}
\hline $\begin{array}{l}\text { Lingkungan } \\
\text { Eksternal }\end{array}$ & $\begin{array}{l}\text { Kekuatan (S) } \\
1 \text { Struktur organisasi yang } \\
\text { tersusun dengan baik } \\
2 \text { Kemudahan mendapat } \\
\text { bahan baku } 3 \text { Memiliki } \\
\text { tenaga kerja yang ahli } \\
\text { dan berpengalaman } \\
4 \text { Berpengalaman dalam } \\
\text { menghasil- kan produk } \\
\text { sepatu yang berku- alitas } \\
5 \text { Citra produk yang sudah } \\
\text { dikenal baik } \\
6 \text { Harga produk yang } \\
\text { terjangkau oleh berbagai } \\
\text { tingkat konsumen }\end{array}$ & $\begin{array}{l}\text { Kelemahan (W) } \\
1 \text { Keterbatasan promosi } \\
\text { yang dilakukan oleh } \\
\text { perusahaan } \\
2 \text { Belum kuatnya brand } \\
\text { image produk yang } \\
\text { dimiliki perusahaan } \\
\text { dibenak konsumen } \\
3 \text { Target penjualan yang } \\
\text { belum sesuai dengan } \\
\text { harapan mandapatkan } \\
4 \text { Sulitnya mendan } \\
\text { tenaga kerja yang } \\
\text { terampil dan terlatih } \\
5 \text { Saluran distribusi yang } \\
\text { terbatas }\end{array}$ \\
\hline $\begin{array}{l}\text { Peluang }(\mathrm{O}) \\
1 \text { Keadaan perekonomian } \\
\text { yang se- makin membaik } \\
2 \text { Perubahan pola dan } \\
\text { gaya hidup masyarakat } \\
3 \text { Kemajuan teknologi } \\
4 \text { Hubungan baik dengan } \\
\text { pemasok bahan baku } \\
5 \text { Hubungan yang baik } \\
\text { dengan buyers yang } \\
\text { berasal dari ins- } \\
\text { tansi/perusahaan } \\
6 \text { Pertumbuhan penduduk } \\
\text { Indonesia sebagai } \\
\text { pangsa pasar potensial } \\
7 \text { Loyalitas konsumen } \\
\text { terhadap produk } \\
\text { perusahaan }\end{array}$ & $\begin{array}{l}\text { Strategi S-O } \\
1 \text { Melakukan promosi dan } \\
\text { mening- katkan } \\
\text { kerjasama dengan distri- } \\
\text { butor/toko-toko untuk } \\
\text { perluasan pasar dalam } \\
\text { usaha meningkatkan } \\
\text { penetrasi produk dan } \\
\text { meningkat- kan volume } \\
\text { penjualan produk (S1, } \\
\text { S5, S6, O1, O5, O6) } \\
2 \text { Pemanfaatan kemajuan } \\
\text { teknologi meningkatkan } \\
\text { untuk dan pelayanan } \\
\text { mutu dan } \\
\text { terhadap buyers (S2, S3, } \\
\text { S4, O2, O3) }\end{array}$ & $\begin{array}{l}\text { Strategi W-O } \\
1 \text { Peningkatan kualitas } \\
\text { SDM melalui program- } \\
\text { program pendidikan } \\
\text { dan pelatihan serta } \\
\text { memadukan seluruh } \\
\text { komponen SDM } \\
\text { untuk mewujudkan total } \\
\text { quality service (W1, } \\
\text { W4, W5, O4, O5) } \\
2 \text { Brand building melalu } \\
\text { peningkatan } \\
\text { promosi (W1, W2, W3, } \\
\text { W4, O5, O6, O7) } \\
3 \text { Melakukan } \\
\text { pemberdayaan } \\
\text { karyawan sebagai } \\
\text { Marketing Public } \\
\text { Relation dalam upaya } \\
\text { terus menjalin } \\
\text { hubungan yang } \\
\text { baik } \\
\text { dengan buyers (W1, } \\
\text { W5, O4, O5, O7) }\end{array}$ \\
\hline
\end{tabular}


ISSN 1412-2936

EISSN 2549-7308

\begin{tabular}{|c|c|c|}
\hline $\begin{array}{l}\text { Ancaman }(T) \\
1 \text { Fluktuasi harga bahan } \\
\text { baku } \\
2 \text { Kenaikan bahan bakar } \\
\text { minyak } \\
3 \text { Penurunan daya beli } \\
\text { masyarakat } 4 \text { Serbuan } \\
\text { produk impor } \\
5 \text { Daya saing produk } \\
\text { domestik yang rendah } \\
\text { dibanding dengan produk } \\
\text { luar } \\
6 \text { Hambatan untuk masuk } \\
\text { industri relatif mudah } \\
7 \text { Kebijakan pemerintah } \\
\text { yang belum mendukung } \\
\text { perkembangan indus- tri } \\
\text { manufaktur tekstil dan } \\
\text { sepatu }\end{array}$ & $\begin{array}{c}\text { Strategi S-T } \\
1 \text { Melakukan inovasi dan } \\
\text { pengem- bangan produk } \\
(\mathrm{S} 2, \mathrm{~S} 3, \mathrm{~S} 4, \mathrm{~T} 4, \mathrm{~T} 5)\end{array}$ & 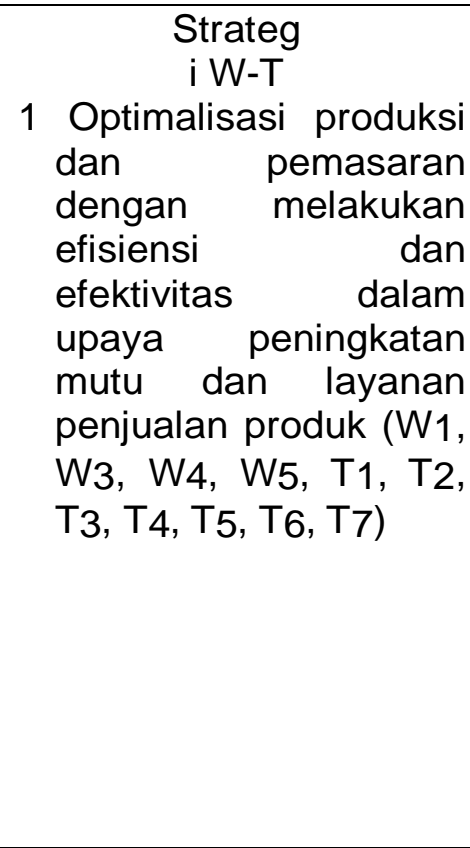 \\
\hline
\end{tabular}

Matriks SWOT (Strengths, Weaknesses, Opportunities and Threats) disusun berdasarkan kekuatan, kelemahan, peluang, dan ancaman yang dimiliki oleh perusahaan yang dibandingkan secara sistematis dan terstruktur bertujuan untuk membentuk empat macam strategi, yaitu strategi, SO, ST, WO, dan WT yang dirinci seperti di bawah ini:

\section{1) Strategi $\mathrm{SO}$}

Strategi SO atau strategi kekuatanpeluang adalah strategi yang menggunakan kekuatan perusahaan untuk memanfaatkan peluang yang ada. Alternatif SO yang dihasilkan antara lain:

1. Melakukan promosi dan mening-katkan kerjasama dengan distri-butor/tokotoko untuk perluasan pasar dalam usaha meningkatkan penetrasi produk dan meningkat-kan volume penjualan produk.

2. Pemanfaatan kemajuan teknologi untuk meningkatkan mutu dan pelayanan terhadap buyers.

2) Strategi ST

Strategi ST atau strategi kekuatanancaman adalah strategi yang menggunakan kekuatan perusahaan untuk mengatasi ancaman dari luar. Alternatif strategi ST yang dihasilkan antara lain: 1. Melakukan inovasi dan pengembangan produk.

\section{3) Strategi WO}

Strategi WO atau strategi kelemahan-peluang adalah strategi untuk memperkecil kelemahan perusahaan dengan memanfaatkan peluang yang ada. Alternatif strategi WO yang dihasilkan antara lain:

1. Peningkatan kualitas SDM melalui program-program pendidikan dan pelatihan serta memadukan seluruh komponen SDM untuk mewujudkan total quality service.

2. Brand building melalui peningkatan promosi.

3. Melakukan pemberdayaan karyawan sebagai Marketing Public Relation dalam upaya terus menjalin hubungan yang baik dengan buyers 
ISSN 1412-2936

EISSN 2549-7308

Tabel 12. Daftar Kekuatan dan Kelemahan Produsen Sandal Desa Pragaan Daya

\begin{tabular}{|c|c|c|}
\hline $\begin{array}{l}\text { Faktor } \\
\text { Internal }\end{array}$ & Kekuatan & Kelemahan \\
\hline $\begin{array}{l}\text { Struktur } \\
\text { Organisasi }\end{array}$ & $\begin{array}{l}\text { Struktur organisasi yang tersusun } \\
\text { dengan baik }\end{array}$ & \\
\hline $\begin{array}{l}\text { Sumberdaya } \\
\text { Perusahaan }\end{array}$ & $\begin{array}{l}\text { Kemudahan mendapat } \\
\text { bahan baku Memiliki } \\
\text { tenaga kerja } \\
\text { ahli dan berpengalaman } \\
\text { Berpengalaman } \\
\text { menghasilkan produk yang } \\
\text { berkualitas } \\
\text { - Citra Produk yang sudah } \\
\text { dikenal baik Harga produk } \\
\text { yang terjangkau oleh } \\
\text { berbagai tingkat konsumen }\end{array}$ & 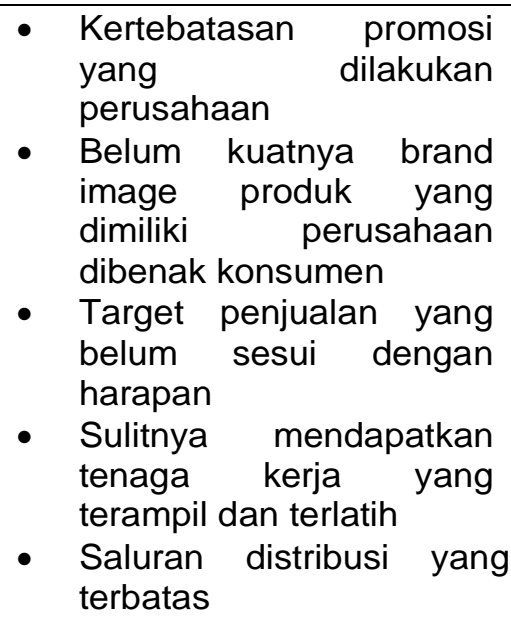 \\
\hline
\end{tabular}

\section{Kesimpulan}

Berdasarkan hasil dan pembahasan yang telah dilakukan, maka dapat diambil beberapa kesimpulan sebagai berikut:

1. Sistem pemasaran yang digunakan oleh produsen sandal desa Pragaan Daya adalah sistem pemasaran langsung (direct marketing). Produk yang dihasilkan perusahaan selama ini adalah sandal dengan konsumen yang dituju antara lain: instansi pemerintah, korporasi, dan masyarakat luas. Perusahaan memandang penting hubungannya dengan pelanggan mereka terutama pelanggan setia yang berasal dari korporasi dan instansi pemerintah dengan terus menjaga hubungan baik tersebut. Sedangkan untuk promosi merk sepatu yang dimiliki, sandal desa Pragaan Daya hanya mengandalkan promosi yang terbatas. Adanya kendala yang harus dihadapi perusahaan telah mempengaruhi pencapaian penjualan perusahaan di tahun 2018, hal itu ditunjukkan oleh penurunan angka penjualan perusahaan di tahun tersebut.

2. Dari hasil identifikasi terhadap faktor internal perusahaan didapatkan kekuatan yang dimiliki perusahaan, yaitu: (1) struktur organisasi yang tersusun dengan baik, (2) kemudahan mendapat bahan baku, (3) memiliki tenaga kerja yang ahli dan berpengalaman, menghasikan produk sepatu yang berkualitas, (5) citra produk yang yang sudah dikenal baik, (6) harga produk yang terjangkau oleh berbagai tingkat konsumen. Adapun faktor kelemahan perusahaan adalah (1) keterbatasan promosi yang dilakukan oleh perusahaan, (2) belum kuatnya brand image produk yang dimiliki perusahaan dibenak konsumen, (3) target penjualan yang belum sesuai dengan harapan, (4) sulitnya mendapatkan tenaga kerja yang terampil dan terlatih, (5) saluran distribusi yang terbatas. Sedangkan dari hasil identifikasi terhadap faktor eksternal perusahaan, maka yang menjadi peluang perusahaan yang bisa dimanfaatkan, yaitu: (1) keadaan perekonomian yang 
semakin membaik, (2) perubahan pola dan gaya hidup masyarakat, (3) kemajuan teknologi, (4) hubungan baik dengan pemasok bahan baku, (5) hubungan yang baik dengan buyers yang berasal dari instansi/perusahaan, pertumbuhan penduduk Indonesia sebagai pangsa pasar potensial, (7) loyalitas konsumen terhadap produk perusahaan. Sedangkan faktor-faktor yang menjadi ancaman bagi perusahaan dalam pemasaran produk perusahaan adalah (1) fluktuasi harga bahan baku, (2) kenaikan bahan bakar minyak, (3) penurunan daya beli masyarakat, (4) ancaman serbuan produk impor, (5) daya saing produk domestik yang rendah dibanding dengan produk luar, (6) hambatan untuk masuk industri relatif mudah, (7) kebijakan pemerintah yang belum mendukung perkembangan industri manufaktur tekstil dan sepatu.

3. Berdasarkan analisis matriks IE perusahaan berada pada posisi kuadran $\mathrm{V}$ dimana perusahaan berada pada kondisi internal dan eksternal yang sedang. Adapun strategi yang dapat ditetapkan oleh perusahaan adalah strategi pertahankan dan pelihara (hold and maintain) berupa strategi penetrasi pasar dan pengembangan produk. Berdasarkan analisis SWOT diperoleh alternatif-alternatif strategi pemasaran yang dapat dilakukan oleh perusahaan. Alternatif-alternatif strategi yang dihasilkan disederhanakan kemudian dianalisis menggunakan QSPM untuk memperoleh urutan prioritas alternatif strategi pemasaran yang direkomendasikan. Berdasarkan analisis QSPM, strategi utama yang diprioritaskan adalah brand building melalui peningkatan promosi. Strategi brand building adalah strategi yang sangat penting dalam pemasaran suatu produk karena dapat meningkatkan loyalitas dan jumlah konsumen produk perusahaan. Strategi ini dilakukan melalui promosi pada pameran dan iklan di media dengan pemilihan waktu yang tepat agar usaha promosi berjalan dengan efektif dan dan efisien.

\section{Saran}

Dari hasil penelitian yang dilakukan diperoleh beberapa saran yang dapat dikemukakan, yaitu:

1. Perusahaan sebaiknya meningkatkan promosi produk dengan memperluas promosi melalui media yang beragam seperti cetak, media elektronik, spanduk, pameran/showroom. Dalam rangka meningkatkan modal kerja dalam mendukung hal tersebut, perusahaan dapat menjalin kerjasama dengan lembaga-lembaga keuangan. Sedangkan untuk meningkatkan kualitas sumberdaya manusia yang dimiliki perusahaan, perusahaan dapat mengikutkan karyawan dalam pelatihan-pelatihan yang diselenggarakan oleh perusahaan atau seminar-seminar luar yang membuka wawasan dan pengetahuan karyawan. Kerjasama dengan toko/agen distribusi akan diperlukan oleh perusahaan untuk meningkatkan penetrasi produk sehingga bisa menjangkau daerah potensial yang masih belum terjangkau serta untuk memastikan ketersedian produk dalam mengantisipasi permintaan masyarakat.

2. Terkait dengan kebijakan yang ada, pemerintah diharapkan dapat mengeluarkan kebijakan yang mendukung industri manufaktur sepatu dan tekstil. Di samping itu pembinaan terhadap UKM lebih ditingkatkan, misalnya dalam pengelolaan manajemen.

3. Strategi yang diimpelementasikan harus disertai dengan pengawasan dan evaluasi dari para manajer 
perusahaan, sehingga strategi yang dijalankan dapat diikuti oleh seluruh pihak manajemen perusahaan dan karyawan, yang pada akhirnya tujuan strategi tersebut akan dapat tercapai.

\section{Daftar Pustaka}

Assauri, Sofyan. 1999. Manajemen Pemasaran. PT. Raja Grafindo Persada Jakarta.

David, Fred R. 2002. Manajemen Strategis. Edisi Ketujuh. PT. Prenhallindo. Jakarta.Glueck, William F. Dan Lawrence R. Jauch. 1996. Manajemen Strategis dan Kebijakan Perusahaan. Edisi Ketiga. Erlangga. Jakarta.

Jauch, Lawrence R. Dan William F. Gleuck 1998. Manajemen Strategis dan Kebijakan Perusahaan. Erlangga. Jakarta.

Kartajaya, H., Mussry J., dan Taufik. 2005. Markplus on Strategy. PT. Gramedia

Pustaka Utama. Jakarta.

Kinnear, T.I. and Taylor.1991. Marketing Research An Applied Approach.. Fourth Edition. USA. Mc Grawhill.

Kotler, P. 1997. Manajemen Pemasaran: Analisis, Perencanaan, Implementasi, dan Kontrol. Edisi Kesembilan. Prenhallindo. Jakarta.

Pearce, J.A. dan Robinson, R.B. 1997. Manajemen Strategi: Formulasi, Implementasi dan Pengendalian. Edisi Satu. Terjemahan. Bina Rupa Aksara. Jakarta.

Porter, Michael E. 1995. Keunggulan Bersaing. Bina Rupa Aksara. Jakarta.

Rangkuti, F. 2001. Analisis SWOT Teknik Membedah Kasus Bisnis. Gramedia Pustaka Utama. Jakarta. 